\title{
Covid-19 Pandemic: Zainon Abdullah's Expression Through Artworks
}

\author{
Siti Humaini Said Ahmad @ Syed Ahmad ${ }^{1}$, Muhamad Rozali Othman ${ }^{2}$ \\ Faculty of Art \& Design, Universiti Teknologi MARA Perak Branch, \\ Seri Iskandar Campus, 32610 Seri Iskandar, Perak Malaysia \\ Authors' Email: 'huemaini@uitm.edu.my, ${ }^{2}$ rozali719@uitm.edu.my
}

Published: 28 September 2020

\begin{abstract}
The outbreak of the Covid-19 Pandemic has gravely impacted various sectors, such as the economy, tourism and education industries. It is also affecting social activities and the standards of everyday life. The effects it has on the art community includes the suspension of many art exhibitions and even the cancellation of these events when the MCO (Movement Control Order), designed to curb and contain the spread of the virus, was implemented by the government. In response, an initiative by prominent local artist Zainon Abdullah to hold a virtual exhibition of his work began. Throughout the partial lockdown, he delivers his artistic expressions through the lens of a world coloured by Covid-19. This study has identified certain themes like nature, the divine, environmental awareness, submission and resurrection in his artwork as extensions of the artist's emotional landscape. Research concludes that this series of Zainon Abdullah's artworks can be classified by phases wherein each phase represents a different order of shapes, meanings and messages while still operating within the restrictions of Covid19. Thus, Zainon Abdullah's work has become a chronologically recorded documentation of an artist's reaction towards a momentous event in world history.
\end{abstract}

Keywords: pandemic COVID-19, virtual art exhibitions, expression artwork.

eISSN: 2550-214X (c) 2020. The Authors. Published for Idealogy Journal by UiTM Press. This is an Open Access article distributed under the terms of the Creative Commons Attribution-NonCommercial-NoDerivatives License (http://creativecommons.org/licenses/by-nc-nd/4.0/), which permits non-commercial re-use, distribution, and reproduction in any medium, provided the original work is properly cited, and is not altered, transformed, or built upon in any way.

\section{INTRODUCTION}

The pandemic nature of the COVID-19 virus has shaken the whole world. The virus known as novel coronavirus was declared by the World Health Organization as pandemic and renamed COVID-19 (Ducharme 2020). In Malaysia especially, the government has implemented the Movement Control Order (MCO) as a proactive measure to curb the epidemic from getting worse. The MCO is enforced in Malaysia in March 2020 due to the pandemic and is closely referred to the Prevention and Control of Infectious Diseases Act 1988 and the Policing Act of 1967 and were enforced in March 2020.

The pandemic has left a huge impact on many sectors such as economy, tourism, industrial, business and trade, and has even changed social activities and living norms of the society. The creative industry sector is also badly affected due to the pandemic. The field of visual arts is especially affected due to the postponement of art exhibitions with possibilities of it being cancelled once and for all. In order to ensure the survival of visual artists, even the galleries have taken initiatives and one such is to have virtual art exhibitions online. Nizam Rahmat (2020) thinks that the use of social media is one of the best methods for the time-being as well as in the near post-MCO period for artists and galleries to reach out to enthusiasts.

One of the Nation's prominent visual artists, Zainon Abdullah has held his first virtual solo exhibition last May during the MCO period. In his opinion, the MCO period is not a limitation for him to continue on producing artworks and having exhibitions. Furthermore, an increasing number of local and international art exhibitions have started shifting to the virtual platform. According to Zainon Abdullah (2020) he also joined the bandwagon by handling a solo exhibition through existing virtual platform, 
his blog. The exhibition known as " 1 st Online - SOLOexhibition - Zainon Abdullah" was held on 14 May 2020 through his very own Studio Kawtsar (telagafakir) blog site.

Zainon Abdullah has actively producing artworks and paintings since 1993 until present. With nearly 30 years of experience in visual arts scene, this Kedah borne artist is also a senior lecturer at UiTM Perak in Seri Iskandar. Armed with vast knowledge and experiences, he also curated some exhibitions both local and international such as in Japan. Apart from exhibitions, he has also won several art competitions local and abroad. Among such competitions is semi-finalist in the 3rd Oita Public Sculpture Japan, Honourable Mention Philip Morris, and first runner-up in the Sand Sculpture Competition Hong Kong as well as the competition jointly organized by Formula Malaysia and Galeri Shah Alam. Zainon Abdullah also has experienced becoming a resident artist at the Nagoya University of Art Japan.

Zainon Abdullah takes the nature elements that he can find around the house as his subject matter. His lawn is aptly decorated with a variety of unique plants and greeneries that is inspired by the Japanese rock garden concept. His experience as a resident artist in Japan has more or less inspired him to infuse Japanese elements into his garden scape. Zainon Abdullah (2020) added that the spatial area does indeed influence an artist whereby well-arranged space combined with inspirational plants and greeneries have a soothing and relaxed effect that will in return spark the idea to produce paintings and artworks. His studio where he works his magic is named Studio Kawtsar, situated next to his house in Tronoh, Perak.

\subsection{Objectives}

The objectives of the research are listed below:

1 To identify elements imbued in Zainon Abdullah's artworks that relate to the Covid-19 Pandemic.

2 To achieve a conclusion on the production of a thematic artwork, such as the ones by Zainon Abdullah, that can be used as reference for art practitioners.

\section{RESEARCH METHODOLOGY}

The data obtained to analyse the idea and expression of the artist is through the process of interview with the artist himself. According to Collins (2010) the advantage of interview method is that the interviewer can get a more precise and concise first-hand information, while at the same time able to control the situation during the interview. In this study the researcher applied the semi-structured interview method whereby the interview is focused by asking certain questions but with scope for the respondent to express himself or herself at length. Interview with the artist were carried-out on 21 July 2020 at the artist's residence in Tronoh, Perak. Apart from that, data obtained are also supported by information from catalogues, books and the artist's own blog entries.

\section{INTUITIVE IDEAS AND EXPRESSIONS OF COVID-19 INSPIRED ARTWORKS}

Zainon Abdullah has expressed his thoughts relating the pandemic viral situation in his paintings. The semi-abstract paintings were produced during the MCO period. According to the artist, he disciplined himself by painting only after completing his Dhuha Prayer for the day during Ramadhan. His paintings were exhibited through his own weblog and received positive attentions and feedbacks from art enthusiasts. He added that the social media is seen as a good alternative in connecting art with the society.

In analysing the paintings, the artist used styles of the Expressionist combined with eastern art elements with a more controlled brush stroke. Aznan Omar (2019) said that recent artworks by Zainon Abdullah is local abstract inspired by practical postmodernist sparked by the clash of eastern and western art movements. The Expressionist style can be seen at the background of each of his paintings 
with rough and expressive colour splash and strokes. According to Ahmad Rashidi (2001) the Expressionist style sees the artist lash out their emotions through fierce warm colours and equally fierce brush strokes.

\subsection{Element of Nature}

In his artwork entitled Tari Rimba: Mimpi Ngeri Novela Corona (2020) and Tari Rimba: COVID19- Dunia Seperti Terjungkit (2020), the artist envisioned torrential movements that feels like hurricane. The artist explained that the image derived from the impression of the earth devouring trees and forest that inflict fear, restlessness and horror. The earth seemed like it is jolted and devastated by the COVID19 pandemic. Images that resemble trees are presented diagonally, thus provides imbalance. Alan Pipes (2013) explained how diagonal lines suggest stressfulness and conflict. Image that resembles hurricane or typhoon would normally come out of subconscious intuitive feelings that were not planned.

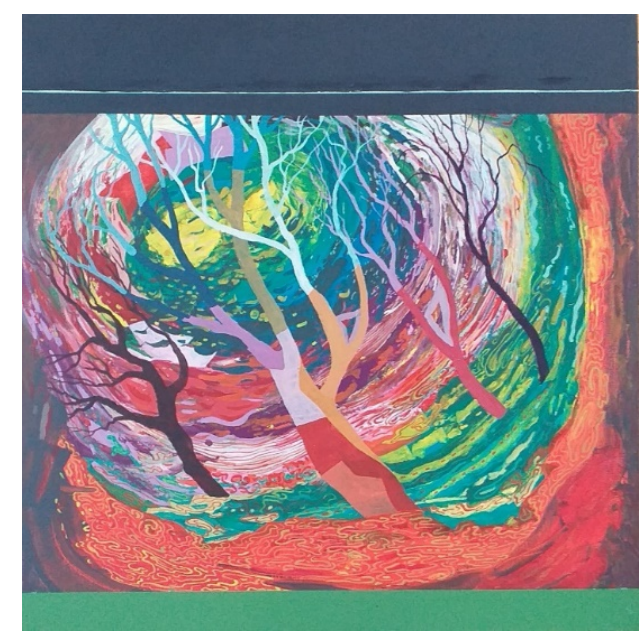

Figure 1: Artwork by Zainon Abdullah, Tari Rimba, Mimpi ngeri Novela Corona (2020), Acrylic on Canvas, $70 \times 70 \mathrm{~cm}$

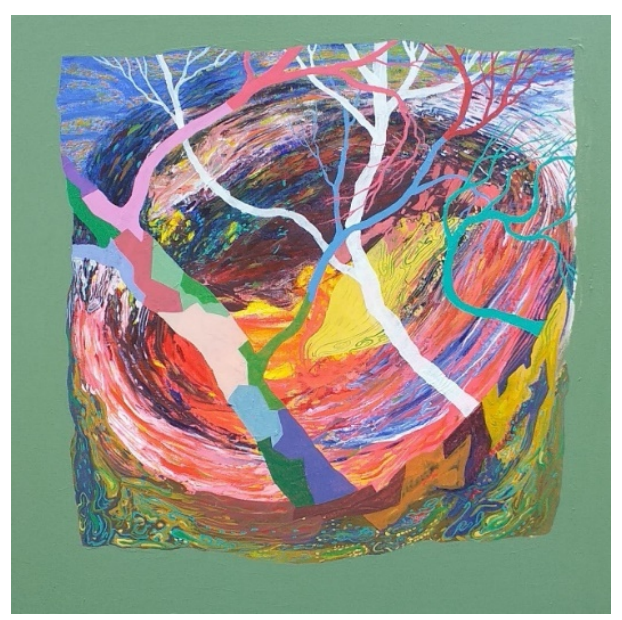

Figure 2: Artwork by Zainon Abdullah, Tari Rimba: Covid 19- Dunia Seperti Terjungkit (2020), Acrylic on Canvas, $70 \times 70 \mathrm{~cm}$

The artist also thinks that the pandemic is like a silent tsunami. Looking back, the impact of the tsunami is very grave whereby many lives were lost as well as properties and belongings, as with the pandemic that took many lives in a short period. Tari Rimba: Covid-19 Tsunami Senyap (2020) is the artist interpretation of the silent tsunami. The border in this painting was not planned. The artist expressed his emotion of being in entrapment and panic state of $\mathrm{MCO}$ at the time of production. During the MCO period, the nation is in lockdown and everyone is expected to stay at home. Only head of families are allowed to shop for groceries and supplies. 


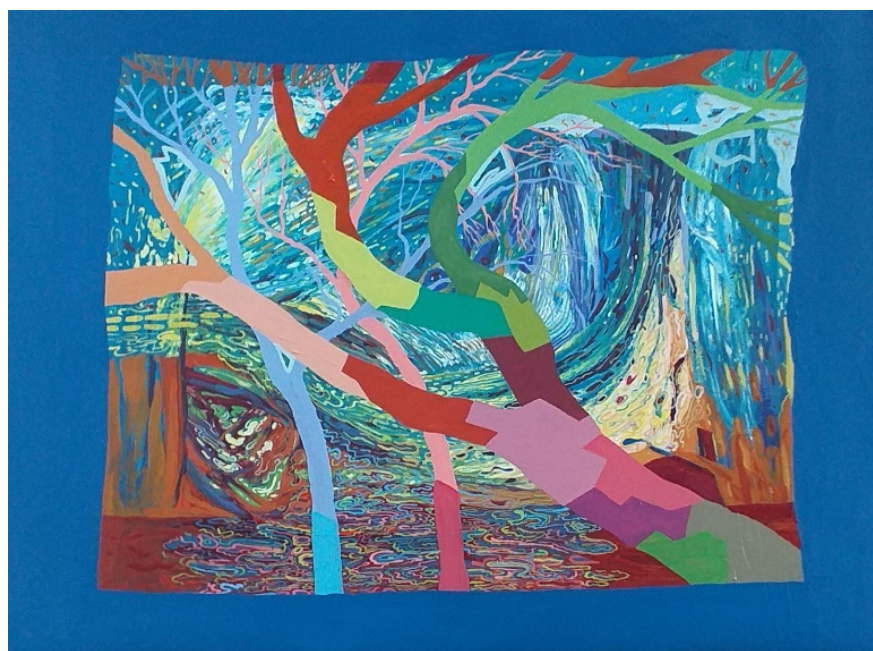

Figure 3: Artwork by Zainon Abdullah, Tari Rimba: Covid-19 Tsunami Senyap (2020), Acrylic on Canvas, 70 x $92 \mathrm{~cm}$

\subsection{Element of The Divine}

Faced with the tragedy of the pandemic, the artist took a self-reflective approach. He added how many do not expect the whole world in lockdown. This shows the power of God as the owner of this earth. Tari Rimba: Corona Datang Bersama Pintu Taubat (2020) and Tari Rimba: Covid 19- Ya Allah Ampuni Kami (2020) is an expression of the artist's feelings of getting closer to the Almighty Creator. Expressions of the artist's consciousness are translated in a work entitled Tari Rimba: Covid 19- Ya Allah Ampuni Kami (2020) by producing a subjective and mysterious landscape. The role of the red and orange colors expressed in this painting reminds us of the plague that befell mankind. Fear of this pandemic plague creates a sense of repentance. This work evokes feelings of fear, tragedy and mystery which have similarities in Edvard Munch's work, The Scream in 1983.

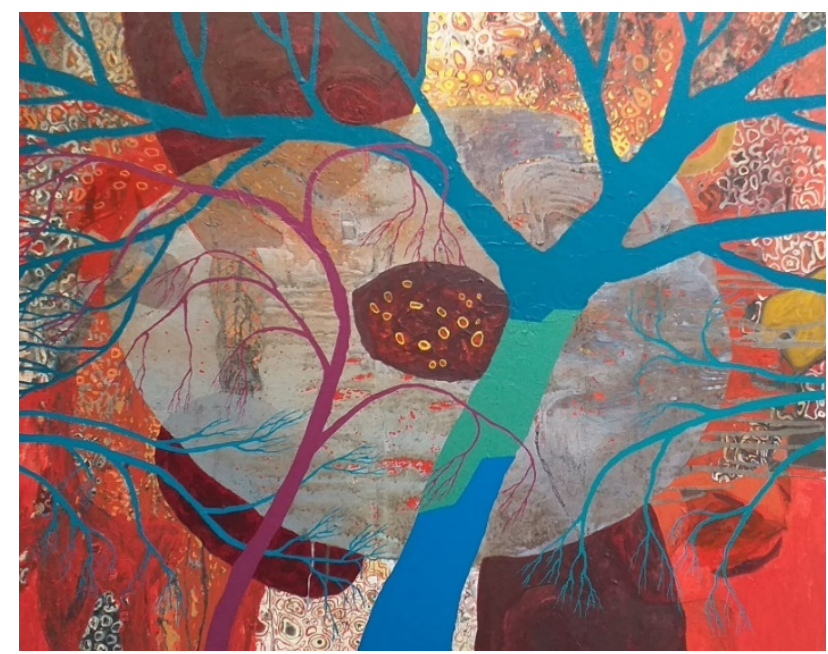

Figure 4: Artwork by Zainon Abdullah, Tari Rimba: Corona Datang Bersama Pintu Taubat (2020), Acrylic on Canvas, $134 \times 109 \mathrm{~cm}$ 


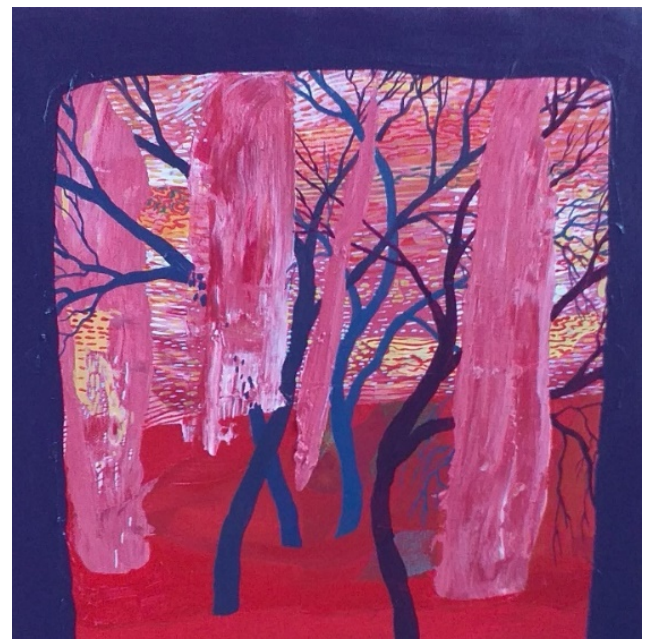

Figure 5: Artwork by Zainon Abdullah, Tari Rimba: Covid 19- Ya Allah Ampuni Kami (2020), Acrylic on Canvas, 38 x 38cm

\subsection{Element of Environmental Awareness}

With every misfortune that occurs, there must be wisdom behind it. The artist has also translated the wisdom behind the coronavirus pandemic in his work entitled Tari Rimba: Kesunyian Dek Corona (2020). The artist states the expression of calmness with the use of cool colors such as blue and green, which gave birth to a sense of peace and the use of horizontal lines reflect calmness. This can be attributed to the impact of this disaster causing the quality of the environment to improve. When the government issued the MCO in which all activities including the industrial, tourism and services sectors are discontinued, decreased number of vehicles became one of the factors in the improvement of environmental quality. This improved air quality can be seen in the blue and clean colors of the clouds like the colors used in the artist's painting.

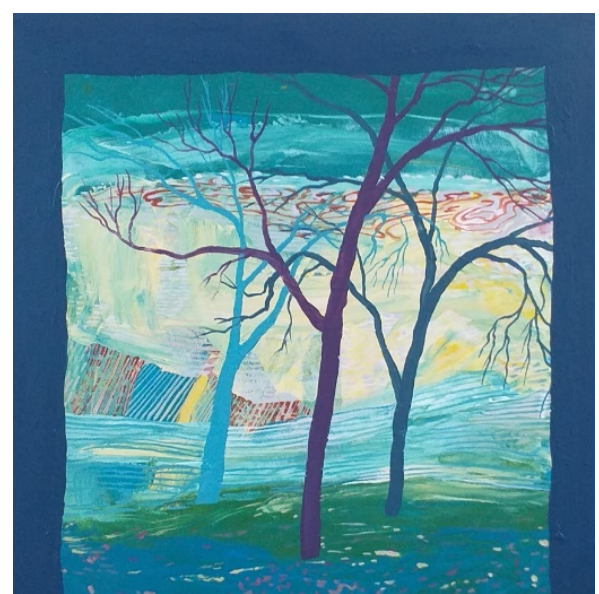

Figure 6: Artwork by Zainon Abdullah, Tari Rimba: Kesunyian Dek Corona (2020), Acrylic on Canvas, 38 x 38cm

\subsection{Element of Submission}

According to Zainon Abdullah (2020), if you produce an artwork based on existing images, the artist might be controlled by the image while the expressive effect is when the situation and experience controls the artist. The paintings entitled Tari Rimba: Terkurung, Tari Rimba: Covid 19; Terbelenggu, Tari Rimba: Covid 19- Langit Masih Suram, Tari Rimba: Ruang Udara Masih Ada Covid 19 are an expression of the artist during the COVID-19 period. Feelings of being shackled, restricted and low- 
spirited are translated visually with the resulting of the "framed border" image in these works. This frame carries a sense of not being free and confined while going through the pandemic situation.

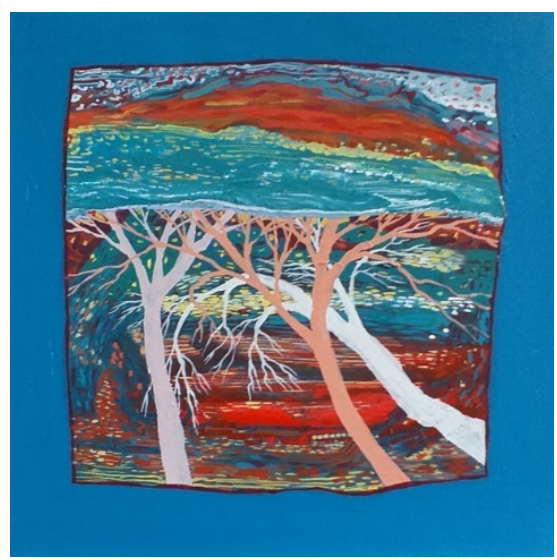

Figure 7: Artwork by Zainon Abdullah, Tari Rimba: covid 19. Terbelenggu (2020), Acrylic on Canvas, $38 \times 38 \mathrm{~cm}$

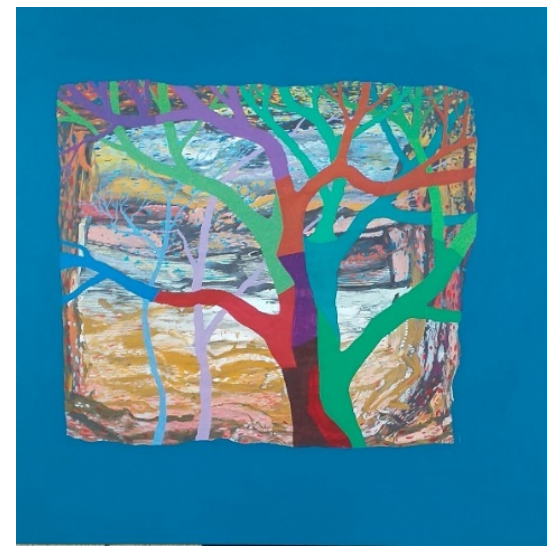

Figure 8: Artwork by Zainon Abdullah, Tari Rimba: terkurung (2020), Acrylic on Canvas, $70 \times 70 \mathrm{~cm}$

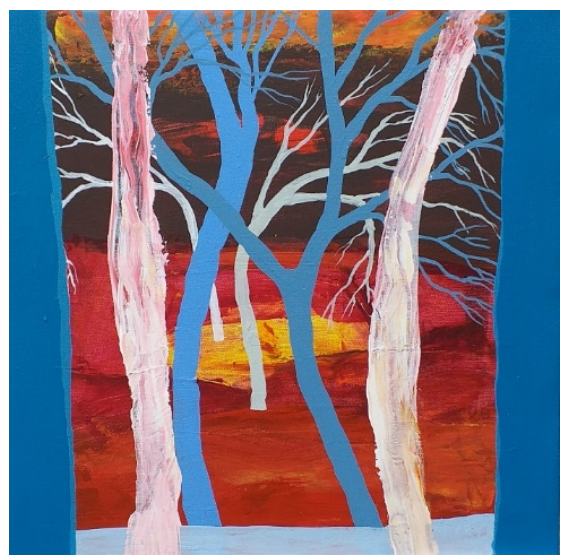

Figure 9: Artwork by Zainon Abdullah, Tari Rimba: covid 19- Langit masih suram (2020), Acrylic on Canvas, $38 \times 38 \mathrm{~cm}$

\subsection{Element of Resurrection}

After going through the difficult moments of COVID-19, the next phase is considered as a ray in the fight against COVID-19. According to Zainon Abdullah (2020) it is better to leave the horror to God; besides, the trees also recite dzikr for fear of Allah let alone human beings. This can be seen in the 
works entitled Tari Rimba: Angin Covid 19- Sinar Harapan 1, Tari Rimba: Angin Covid 19- Sinar Harapan 2, Tari Rimba: Angin Covid 19- Sinar Harapan 6, Tari Rimba: Angin Covid 19- Sinar Harapan 8, dan Tari Rimba: Angin Covid 19-Sinar Harapan 9. In these paintings, the artist has simplified the trees into abstract images. Furthermore, the image of the leaves is simplified to be oval so that it looks calm and not cluttered. The leaves are depicted as floating since they contain oxygen for humans. In the image of the main tree trunk, the artist summarized the image with endless lines to show the features of repetitive dhikr chants by enhancing small units of endless lines.

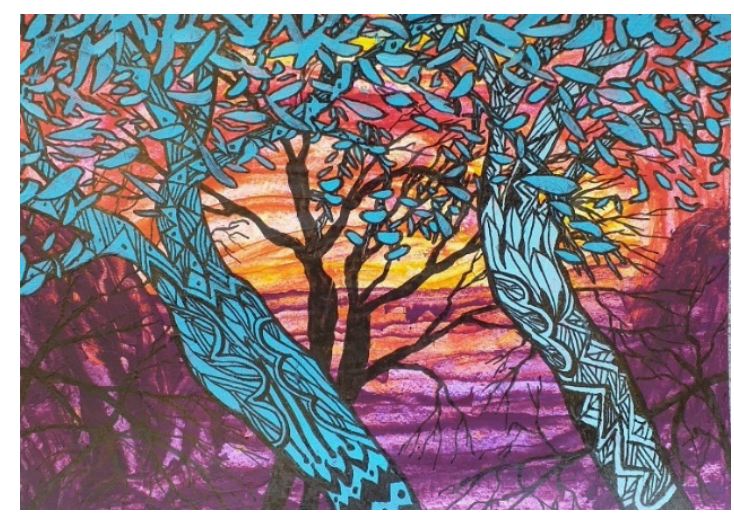

Figure 10: Artwork by Zainon Abdullah, Tari Rimba: Angin Covid 19- Sinar Harapan 1 (2020), Ink and acrylic on paper, $42 \times 29.5 \mathrm{~cm}$

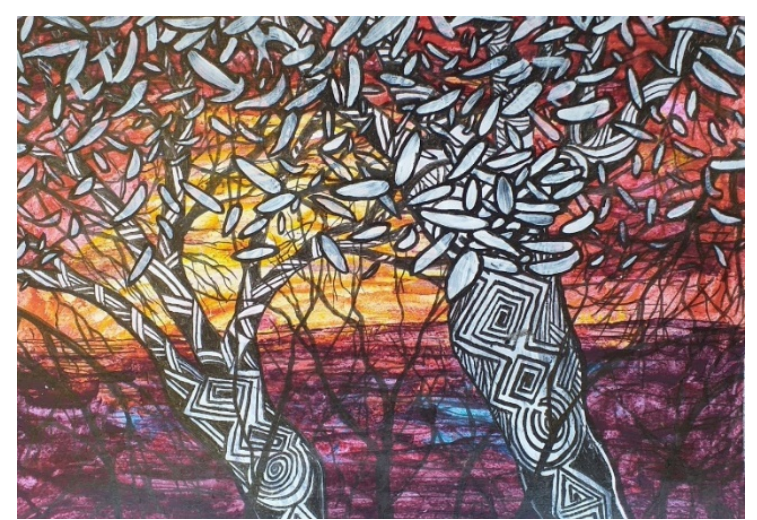

Figure 11: Artwork by Zainon Abdullah, Tari Rimba: Angin Covid 19- Sinar Harapan 2 (2020), Ink and acrylic on paper, $42 \times 29.5 \mathrm{~cm}$

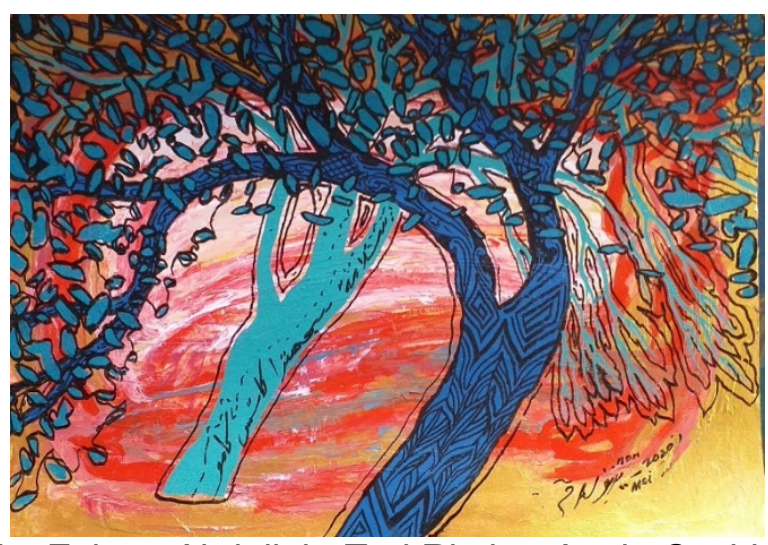

Figure 12: Artwork by Zainon Abdullah, Tari Rimba: Angin Covid 19- Sinar Harapan 8 (2020), Ink and acrylic on paper, $42 \times 29.5 \mathrm{~cm}$ 


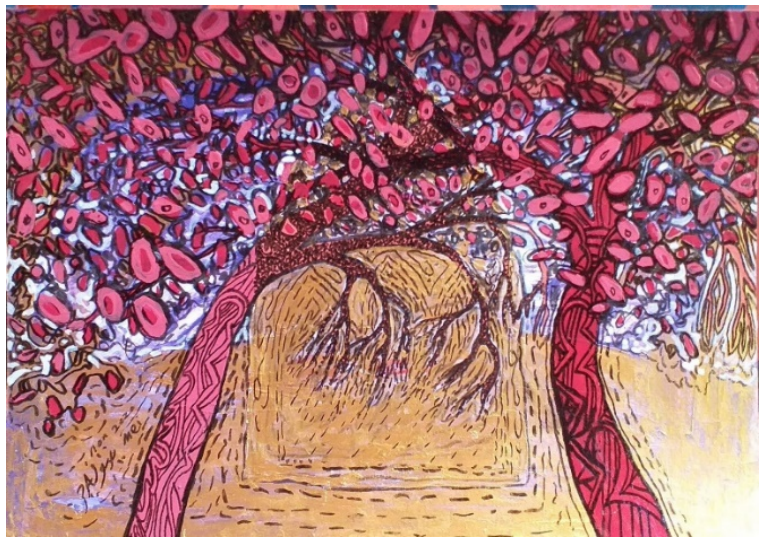

Figure 13: Artwork by Zainon Abdullah, Tari Rimba: Angin Covid 19- Sinar Harapan 9 (2020), Ink and acrylic on paper, $42 \times 29.5 \mathrm{~cm}$

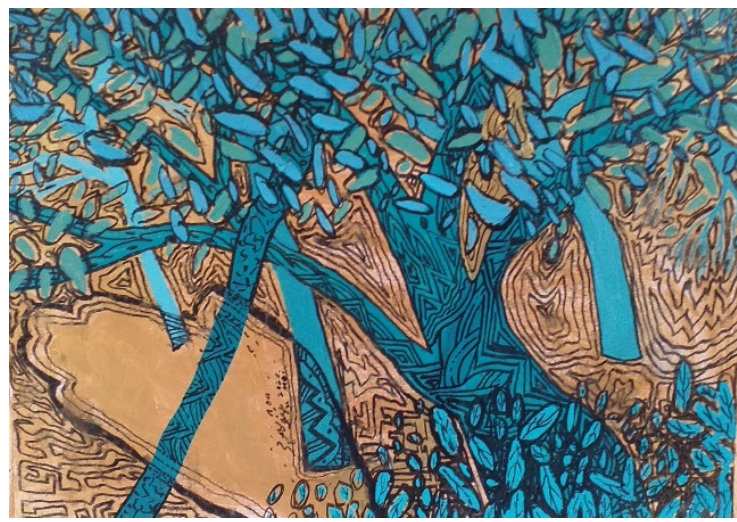

Figure 14: Artwork by Zainon Abdullah, Tari Rimba: Angin Covid 19- Sinar Harapan 6 (2020), Ink and acrylic on paper, $42 \times 29.5 \mathrm{~cm}$

\section{CONCLUSION}

From this research, it can be inferred that Zainon Abdullah has brought in the theme of Covid-19 in his artwork within a few phases. When compared to the Movement Restriction Order in Malaysia, there is a similarity in chronology. Within the partial lockdown, there are phases of MCO, CMCO (Conditional Movement Control Order) and RMCO (Recovery Movement Control Order). In the context of Zainon Abdullah's artistic designs, the artist views the pandemic as first a catastrophe, then an awakening and finally, a resurrection.

In the catastrophic state, he depicts the pandemic that engulfed the globe as a deadly combination of a hurricane and a tsunami that surge without warning and cause great devastation. He demonstrates his perception through naturalistic elements such as trees, which are diagonally visualised as being mercilessly beaten by strong winds. In the next phase, Zainon Abdullah brings us to the realisation of God's power, in that the pandemic is a test for mankind and that we must surrender before Him and humble ourselves, as well as repent from our sins. Repentance is conveyed by creating a subjective and mysterious landscape in the painting, that can only be deciphered through individual lenses. The final phase, that of Resurrection, he illustrates in his artworks that man and nature are both recovering slowly, full of newfound awareness and hope. His emotions are articulated through sketches of abstract trees but simplified, with the leaves made oblong and appearing calm. 
Zainon Abdullah has succeeded in bringing the theme of the Covid-19 pandemic within his own unique context. The use of elements related to nature, godliness and a rising after death results in a great impression of his work. Thus, Zainon Abdullah's work has become a chronologically recorded documentation of an artist's reaction towards a momentous event in world history.

\section{REFERENCES}

Ahmad Rashidi Hasan, (2001). Sejarah Seni Lukis Sepintas Lalu Siri Pengajian Seni Karisma. Kuala Lumpur: Karisma Pubs.

Aznan Omar (2020) Zainon Abdullah: Perjalanan 2002-2019. Retrieved July 19, 2020 from http://gab.fssrperak.com/Exhibition/pameran-solo-zainon-abdullah-perjalanan-2002-2019/

Collins, H. (2010). Creative Research. United Kingdom: AVA Publishing SA.

Ducharme, J. (2020) World Health Organization Declares COVID-19 a 'Pandemic.' Here's What That Means. Retrieved July 28, 2020 from https://time.com/5791661/who-coronavirus-pandemicdeclaration/

Irwan Muhammad Zain (2020). COVID-19: Ketika atau selepas PKP, seniman jangan berhenti berkarya- Nizam Rahmat Retrieved July 17, 2020 from http://www.astroawani.com/gayahidup/covid-19-ketika-atau-selepas-pkp-seniman-jangan-berhenti-berkarya-nizam-rahmat-237556

Pipes, A. (2008). Fundations of Art and Design. United Kingdom: Laurence King Publishing Ltd.

Zainon Abdullah (2020). 1st online - SOLOexhibition - Zainon Abdullah Retrieved Julai 20, 2020 from http://zainonabdullah.blogspot.com/2020/05/my-artworks.html

Zainon Abdullah (2020, July 21) Artist. Personal Interview.Perak. 
Idealogy Journal

Volume 5 Issue 22020
溇: IDEALOGY

JOURNAL 